\author{
Arkadiusz Bereza \\ Uniwersytet Marii Curie-Skłodowskiej w Lublinie, Polska \\ ORCID: 0000-0002-3964-9179 \\ arkadiusz.bereza@poczta.umcs.lublin.pl
}

\title{
Glosa do wyroku Sądu Apelacyjnego we Wrocławiu z dnia 29 października 2019 r. (I ACa 698/19, niepublikowany)
}

\author{
Gloss to the Judgement of the Court of Appeal in Wrocław \\ of 29 October 2019 (I ACa 698/19, not published)
}

\section{STRESZCZENIE}

Sąd Apelacyjny we Wrocławiu w wyroku z dnia 29 października 2019 r. (I ACa 698/19), zmieniając wyrok Sądu Okręgowego we Wrocławiu z dnia 28 lutego 2019 r. (I C733/18), uznał za nieważne nabycie nieruchomości przez obywatela Korei Południowej. W glosowanym wyroku Sąd Apelacyjny we Wrocławiu dokonał wykładni art. 8 ust. 2 ustawy z dnia 24 marca 1920 r. o nabywaniu nieruchomości przez cudzoziemców. Przepis dotyczy zakresu podmiotowego zwolnienia z obowiązku uzyskania zezwolenia ministra właściwego dla spraw wewnętrznych na nabycie nieruchomości. Sąd Apelacyjny uznał, że osoba fizyczna będąca cudzoziemcem w rozumieniu ustawy o nabywaniu nieruchomości przez cudzoziemców, nieposiadająca obywatelstwa państwa - strony umowy o Europejskim Obszarze Gospodarczym albo Konfederacji Szwajcarskiej, mimo że prowadzi indywidualną działalność gospodarczą na terytorium Rzeczypospolitej Polskiej, nie korzysta ze zwolnienia przewidzianego w art. 8 ust. 2 tej ustawy, dotyczącego obywateli i przedsiębiorców państw - stron umowy o Europejskim Obszarze Gospodarczym albo Konfederacji Szwajcarskiej, gdyż jest to sprzeczne z funkcją ustawy o nabywaniu nieruchomości przez cudzoziemców oraz z wykładnią systemową i celowościową art. 8 ust. 2 tej ustawy.

Słowa kluczowe: nabywanie nieruchomości przez cudzoziemców; zwolnienie z uzyskania zezwolenia ministra właściwego do spraw wewnętrznych; Traktat Akcesyjny; Europejski Obszar Gospodarczy

W związku z upływem okresów przejściowych przewidzianych w art. 8 ust. 2 ustawy z dnia 24 marca 1920 r. o nabywaniu nieruchomości przez cudzoziemców ${ }^{1}$, a ustanowionych w związku z wejściem Rzeczypospolitej Polskiej do Unii Europej-

1 T.j. Dz.U. 2017, poz. 2278 z późn. zm., dalej: UnNpC. 
skiej, nie ustały wątpliwości uczestników obrotu gospodarczego na tle wykładni tej regulacji. Prowadzą one do sporów przed sądami administracyjnymi, a w przypadku nabycia nieruchomości bez wymaganego zezwolenia - do postępowania sądowego w celu stwierdzenia nieważności jej nabycia.

Przepis art. 8 ust. 2 UnNpC został wprowadzony ustawą z dnia 20 lutego 2004 r. o zmianie ustawy o nabywaniu nieruchomości przez cudzoziemców i ustawy o opłacie skarbowej ${ }^{2}$. Ta duża nowelizacja UnNpC zawierała zredagowane językiem prawnym postanowienia Traktatu Akcesyjnego dotyczące okresowej modyfikacji zasady swobody przepływu kapitału (z art. 56 Traktatu ustanawiającego Unię Europejską) w zakresie obrotu nieruchomościami z udziałem cudzoziemców. Zostały one sformułowane w Załączniku XII (pkt 4 „Swobodny przepływ kapitału”) do art. 24 Aktu dotyczącego warunków przystąpienia Polski do Unii Europejskiej³. Będący przedmiotem analizy art. 8 ust. $2 \mathrm{UnNpC}$ uległ następnie zmianie ukierunkowanej na rozszerzenie zawartego w nim zakresu zwolnienia podmiotowego (poprzez dołączenie obywateli i przedsiębiorców Konfederacji Szwajcarskiej) na podstawie ustawy z dnia 5 września 2008 r. o zmianie niektórych ustaw w związku z wejściem w życie Protokołu do Umowy między Wspólnotą Europejską i jej Państwami Członkowskimi, z jednej strony, a Konfederacją Szwajcarską, z drugiej strony, w sprawie swobodnego przepływu osób ${ }^{4}$. Od tej zmiany (do dziś, a więc także w momencie zdarzenia prawnego będącego przedmiotem rozstrzygnięcia w glosowanym wyroku Sądu Apelacyjnego) art. 8 ust. 2 UnNpC brzmi: „Nie jest wymagane uzyskanie zezwolenia przez cudzoziemców, będących obywatelami lub przedsiębiorcami państw - stron umowy o Europejskim Obszarze Gospodarczym (EOG) albo Konfederacji Szwajcarskiej, z wyjątkiem nabycia: 1) nieruchomości rolnych i leśnych, przez okres 12 lat od dnia przystąpienia Rzeczypospolitej Polskiej do Unii Europejskiej; 2) drugiego domu, przez okres 5 lat od dnia przystąpienia Rzeczypospolitej Polskiej do Unii Europejskiej”.

Oznacza to, że wraz z wstąpieniem Rzeczypospolitej Polskiej do Unii Europejskiej w stosunku do cudzoziemców, będących obywatelami lub przedsiębiorcami państw - stron umowy o EOG (a od 25 października 2008 r. także Konfederacji

2 Art. 1 pkt 13 ustawy z dnia 20 lutego 2004 r. o zmianie ustawy o nabywaniu nieruchomości przez cudzoziemców i ustawy o opłacie skarbowej (Dz.U. nr 49, poz. 466).

3 Akt dotyczący warunków przystąpienia do Unii Europejskiej Republiki Czeskiej, Republiki Estońskiej, Republiki Cypryjskiej, Republiki Łotewskiej, Republiki Litewskiej, Republiki Węgierskiej, Republiki Malty, Rzeczypospolitej Polskiej, Republiki Słowenii i Republiki Słowackiej oraz dostosowań w Traktatach stanowiących podstawę Unii Europejskiej, Załącznik XII „Wykaz, o którym mowa w artykule 24 Aktu Przystąpienia: Polska" (Dz.U. 2004, nr 90, poz. 865; Dz.Urz. UE L 236 z 23.09.2003 r.).

4 Art. 1 ustawy z dnia 5 września 2008 r. o zmianie niektórych ustaw w związku z wejściem w życie Protokołu do Umowy między Wspólnotą Europejską i jej Państwami Członkowskimi, z jednej strony, a Konfederacją Szwajcarską, z drugiej strony, w sprawie swobodnego przepływu osób (Dz.U. nr 180, poz. 1112). 
Szwajcarskiej) $)^{5}$, zostały usunięte ograniczenia publicznoprawne dotyczące nabywania nieruchomości ( $\mathrm{z}$ wyjątkiem wymienionych w art. 8 ust. 2 pkt 1 i 2 UnNpC) oraz nabywania lub obejmowania udziałów i akcji w spółkach handlowych mających siedzibę w Polsce, będących właścicielami lub użytkownikami wieczystymi nieruchomości położonych na terytorium Rzeczypospolitej Polskiej ${ }^{6}$. Te czynności prawne z udziałem obywateli lub przedsiębiorców państw - stron umowy o EOG nie podlegają już reglamentacji administracyjnej, co nie oznacza wyłączenia w tym przypadku stosowania UnNpC. Rozwiązanie to pozwala na ustawowe monitorowanie tej sfery obrotu prawnego przez ministra właściwego do spraw wewnętrznych (art. 8 ust. 4 i $5 \mathrm{UnNpC}$ ), prowadzącego - na podstawie danych przesyłanych przez podmioty zobowiązane - rejestr nieruchomości, udziałów i akcji, nabytych lub objętych przez cudzoziemców bez zezwolenia w przypadkach określonych m.in. w art. 8 ust. $2 \mathrm{UnNpC}^{7}$. Cudzoziemcy w rozumieniu $\mathrm{UnNpC}$, będący obywatelami i przedsiębiorcami państw - stron umowy o EOG albo Konfederacji Szwajcarskiej, są zwolnieni od obowiązku uzyskania zezwolenia ministra właściwego do spraw wewnętrznych albo są zobowiązani do jego uzyskania w przypadku bezpośredniego nabycia określonych rodzajowo nieruchomości w ustawowo wskazanym okresie od dnia przystąpienia Rzeczypospolitej Polskiej do Unii Europejskiej. Oznacza to, że konstrukcja prawna wprowadzona w art. 8 ust. $2 \mathrm{UnNpC}$ ma charakter generalnego zwolnienia podmiotowego przedsiębiorców państw - stron umowy o EOG albo Konfederacji Szwajcarskiej z obowiązku uzyskania zezwolenia ministra właściwego do spraw wewnętrznych, z okresowo ustawowymi wyjątkami o charakterze przedmiotowym, dotyczącymi rodzaju nieruchomości, co stanowiło realizację jednego z filarów funkcjonowania Unii Europejskiej, a mianowicie zasady swobody przepływu kapitału.

5 Europejski Obszar Gospodarczy powstał na mocy układu podpisanego w Porto w dniu 1 maja 1992 r., który wszedł w życie z dniem 1 stycznia 1994 r. Obecnie w jego skład wchodzą państwa członkowskie Unii Europejskiej oraz Norwegia, Islandia i Liechtenstein. Rzeczpospolita Polska weszła do EOG na podstawie podpisanego w Brukseli w dniu 14 października 2003 r. porozumienia w sprawie udziału w Europejskim Obszarze Gospodarczym. Porozumienie zostało ratyfikowane przez Prezydenta Rzeczypospolitej Polskiej w dniu 8 października 2004 r. na podstawie ustawy z dnia 16 kwietnia 2004 r. (Dz.U. 2004, nr 130, poz. 1375) i weszło ono w życie w dniu 6 grudnia 2005 r. Konfederacja Szwajcarska nie wchodzi w skład EOG, jednak jej obywatele korzystają w zakresie nabywania nieruchomości z uprawnień przysługujących obywatelom państw - stron umowy o EOG na mocy Protokołu do Umowy między Wspólnotą Europejską i jej Państwami Członkowskimi, z jednej strony, a Konfederacją Szwajcarską, z drugiej strony, w sprawie swobodnego przepływu osób z dnia 26 października 2004 r., który wszedł w życie 1 kwietnia 2006 r. (Dz.Urz. UE L 89 z 28.03.2006 r.).

6 Wyrok SA w Poznaniu z dnia 2 grudnia 2008 r., I ACa 699/08, Legalis nr 216236; P. Franczak, Powiernicze posiadanie udziałów a ustawa o nabywaniu nieruchomości przez cudzoziemców, „Monitor Prawniczy” 2016, nr 7, s. 359.

7 Taka działalność jest dopuszczalna w świetle art. 65 ust. 1 lit. b Traktatu o funkcjonowaniu Unii Europejskiej. 
Wyrok Sądu Apelacyjnego we Wrocławiu zapadł na tle stanu faktycznego, w którym obywatel państwa niebędącego stroną umowy o EOG ani Konfederacji Szwajcarskiej nabył nieruchomość, tj. działkę gruntu zabudowaną budynkiem mieszkalnym jednorodzinnym, bez zezwolenia ministra właściwego do spraw wewnętrznych.

Przedmiotowe nabycie nieruchomości stanowiło w ocenie ministra właściwego do spraw wewnętrznych naruszenie przepisów ustawy, powodujące nieważność nabycia zgodnie z brzmieniem art. 6 ust. 1 UnNpC. Powyższe skutkowało skorzystaniem przez ministra właściwego do spraw wewnętrznych z uprawnień wynikających z art. 6 ust. 2 UnNpC i wystąpieniem na drogę sądową celem uzyskania orzeczenia stwierdzającego nieważność nabycia nieruchomości.

Pozwany obywatel Korei Południowej oparł swoje stanowisko na możliwości zastosowania zwolnienia $\mathrm{z}$ art. 8 ust. $2 \mathrm{UnNpC}^{8}$ ze względu na przysługujący mu status przedsiębiorcy państwa - strony umowy o EOG (w tym przypadku - Rzeczypospolitej Polskiej). Przemawiał za tym zalegalizowany pobyt na terytorium Rzeczypospolitej Polskiej uprawniający go do prowadzenia na jej terytorium indywidualnej działalności gospodarczej na podstawie wpisu do Centralnej Ewidencji i Informacji o Działalności Gospodarczej. W akcie notarialnym nabycia nieruchomości występował jako przedsiębiorca państwa - strony umowy o EOG, a jej nabycie było dokonane na cele związane z rozpoczętą już działalnością gospodarczą. Ponadto Pozwany, uzasadniając swoje stanowisko, wskazał na brak w przepisach UnNpC definicji przedsiębiorcy, a tym samym na konieczność odwołania się do art. $43^{1}$ k.c., zgodnie z którym: „Przedsiębiorcą jest osoba fizyczna, osoba prawna i jednostka organizacyjna, o której mowa $\mathrm{w}$ art. $33^{1} \S 1$, prowadząca we własnym imieniu działalność gospodarczą lub zawodową", oraz art. 4 ust. 1 ustawy z dnia 2 lipca 2004 r. o swobodzie działalności gospodarczej”, w świetle którego: „Przedsiębiorcą w rozumieniu ustawy jest osoba fizyczna, osoba prawna i jednostka organizacyjna niebędąca osobą prawną, której odrębna ustawa przyznaje zdolność prawną - wykonująca we własnym imieniu działalność gospodarczą". Pozwany podniósł, że wolą ustawodawcy polskiego było zapewnienie swobody nabywania nieruchomości przez przedsiębiorców mających siedzibę w państwie - stronie umowy o EOG, nie różnicując tych podmiotów pod kątem formy prowadzenia działalności, jak również ze względu na posiadane obywatelstwo ${ }^{10}$.

8 Charakter nabywanej nieruchomości oraz status cudzoziemca będącego nabywcą nieruchomości nie dawały podstaw do skorzystania ze zwolnień przewidzianych w art. 8 ust. $1 \mathrm{UnNpC}$.

9 Ustawa z dnia 23 kwietnia 1964 r. - Kodeks cywilny (t.j. Dz.U. 2019, poz. 1145), dalej: k.c. Nabycie nieruchomości miało miejsce w 2016 r., a więc w stanie prawnym, w którym obowiązywała ustawa z dnia 2 lipca 2004 r. o swobodzie działalności gospodarczej (t.j. Dz.U. 2015, poz. 584 z późn. zm.).

10 Poza zakresem analizy pozostaje nietrafiona argumentacja Pozwanego dotycząca posiadania zezwolenia na pobyt rezydenta długoterminowego Unii Europejskiej. Przesłanka ta stanowiłaby 
Minister Spraw Wewnętrznych i Administracji przedstawił inne stanowisko, które uzasadniało jego powództwo. Uznał on, że warunkiem niezbędnym do skorzystania przez cudzoziemca w rozumieniu UnNpC, będącego osobą fizyczną, ze zwolnienia przewidzianego $\mathrm{w}$ art. 8 ust. $2 \mathrm{UnNpC}$ jest posiadanie obywatelstwa jednego z państw - stron porozumienia o EOG albo Konfederacji Szwajcarskiej.

Sąd pierwszej instancji oddalił powództwo Ministra Spraw Wewnętrznych i Administracji, uznając argumentację przedstawioną przez Pozwanego jako odpowiadającą prawu, w której kluczowe znaczenie miała wykładnia art. 8 ust. 2 UnNpC. O jej kierunku zdecydowało przyznanie przez sąd pierwszej instancji twierdzenia Pozwanego - cudzoziemca, że z uwagi na prowadzoną działalność gospodarczą na terytorium Rzeczypospolitej Polskiej jest on przedsiębiorcą państwa - strony umowy o EOG. Nie miało natomiast dla sądu znaczenia, iż Pozwany nie posiadał obywatelstwa żadnego z tych państw. Sąd pierwszej instancji, powołując się na definicje ,przedsiębiorcy” w polskim systemie prawnym, uznał, że kwalifikacja danego podmiotu jako przedsiębiorcy następuje wyłącznie na podstawie kryterium funkcjonalnego, odwołującego się do pojęcia prowadzonej działalności gospodarczej lub zawodowej, i żadna z powołanych w uzasadnieniu definicji nie ogranicza kręgu osób kwalifikujących się jako „przedsiębiorcy” ze względu na posiadane obywatelstwo. Prowadziło to do wniosku, że przedsiębiorcą w rozumieniu art. 8 ust. 2 UnNpC są podmioty prowadzące działalność gospodarczą i mogą to być zarówno osoby prawne, inne jednostki organizacyjne niebędące osobami prawnymi, którym odrębne przepisy przyznają zdolność prawną, jak i osoby fizyczne, na co wskazywałby spójnik „lub” wprowadzający alternatywę nierozłączną - w dyspozycji interpretowanego przepisu - wskazującą na niezależność pojęcia przedsiębiorcy od pojęcia obywatela, tj. osoby fizycznej, co w konsekwencji nie wyklucza sytuacji, aby osoba fizyczna posiadała jednocześnie status przedsiębiorcy w rozumieniu art. 8 ust. 2 UnNpC. Analizując motywy, którymi kierował się sąd pierwszej instancji, należy zwrócić uwagę na powołane w uzasadnieniu postanowienie Sądu Najwyższego z dnia 21 maja 2010 r. (CSK 641/09), w którym - notabene całkowicie zasadnie - uznano, iż spółka z ograniczoną odpowiedzialnością kontrolowana przez obywatela Indii, której siedziba znajduje się na terytorium Rzeczypospolitej Polskiej, jest cudzoziemcem w rozumieniu art. 1 ust. 2 pkt $4 \mathrm{w}$ zW. z pkt $1 \mathrm{UnNpC}$, lecz pozostaje przedsiębiorcą państwa - strony umowy o EOG. Sąd pierwszej instancji nie tylko powołał powyższe postanowienie do nieadekwatnego stanu faktycznego, lecz również wyciągnął z jego treści błędne wnioski dla rozpatrywanej sprawy.

odrębną podstawę do zwolnienia z wymogu uzyskania zezwolenia na nabycie nieruchomości, o ile w chwili nabycia nieruchomości cudzoziemiec zamieszkiwałby na terytorium Rzeczypospolitej Polskiej co najmniej 5 lat od udzielenia zezwolenia na pobyt rezydenta długoterminowego Unii Europejskiej (art. 8 ust. 1 pkt $2 \mathrm{UnNpC}$ ), co w przedmiotowym bezspornym stanie faktycznym nie miało miejsca. 
Od wyroku Sądu Okręgowego we Wrocławiu apelację złożył Minister Spraw Wewnętrznych i Administracji. Po jej rozpatrzeniu Sąd Apelacyjny we Wrocławiu zmienił zaskarżony wyrok i stwierdził nieważność dokonanego przez Pozwanego cudzoziemca nabycia nieruchomości. Uznał, że sąd pierwszej instancji dokonał błędnej interpretacji art. 8 ust. $2 \mathrm{UnNpC}$, a w konsekwencji wadliwie nie zastosował art. 6 ust. $1 \mathrm{UnNpC}$.

Sąd Apelacyjny we Wrocławiu w uzasadnieniu przyjął, iż wykładnia art. 8 ust. 2 UnNpC dokonana przez sąd pierwszej instancji jest sprzeczna z funkcją i celem tej regulacji prawnej. Jeżeli bowiem ustawodawca w jednym przepisie wprowadza dwa pojęcia - na tle sprawy niniejszej „obywatele” i „przedsiębiorcy" - to nie mogą być one tożsame, co oznacza, że zwolnienie dotyczyło osób fizycznych i osób niebędących osobami fizycznymi. Przez użycie spójnika „lub” w art. 8 ust. 2 UnNpC in principio ustawodawca wystarczająco wyraźnie rozróżnił osoby fizyczne (obywateli) od przedsiębiorców (osób prawnych), które to pojęcia w żadnym razie nie są tożsame. Łącznikiem przywileju nabywania przez osoby fizyczne nieruchomości położonych w Polsce bez zezwolenia jest obywatelstwo, będące atrybutem wyłącznie osób fizycznych, a osób prawnych łącznikiem tym jest siedziba przedsiębiorcy. Osoba fizyczna prowadząca działalność na terenie jednego z państw, o których mowa w art. 8 ust. 2 UnNpC, nadal ma status osoby fizycznej, a nie prawnej. W ocenie Sądu Apelacyjnego wykładnia sądu pierwszej instancji, sprowadzająca się do wniosku, że każda osoba fizyczna nieposiadająca obywatelstwa jednego z państw - stron umowy o EOG albo Konfederacji Szwajcarskiej, która zarejestruje działalność gospodarczą w Rzeczypospolitej Polskiej, może nabywać nieruchomości bez zezwolenia, doprowadzi do tego, że to nie łącznik obywatelstwa z określonym państwem, lecz aktywność zawodowa na jego terytorium decydowałaby o zwolnieniu z obowiązku uzyskania zezwolenia, podczas gdy krąg osób fizycznych korzystających z omawianego przywileju został jednoznacznie ograniczony do obywateli ściśle określonej grupy państw. Wykładnia sądu pierwszej instancji oznaczałaby - w ocenie Sądu Apelacyjnego - wprowadzenie w ustawie trzeciej grupy podmiotów (osób fizycznych nieposiadających obywatelstwa jednego z państw - stron umowy o EOG albo Konfederacji Szwajcarskiej, które w tych państwach prowadzą działalność gospodarczą) zwolnionych z obowiązku uzyskania zezwolenia na nabycie nieruchomości. Ponadto Sąd Apelacyjny wskazał, iż wykładnia dokonana przez sąd pierwszej instancji pozbawiałaby sensu art. 1a ust. 2 pkt $5 \mathrm{UnNpC}$, gdyż prowadzenie działalności gospodarczej nie stanowiłoby okoliczności potwierdzającej istnienie więzi z Rzecząpospolitą Polską umożliwiającej uzyskanie zezwolenia, lecz byłoby wprost podstawą do zwolnienia z obowiązku uzyskania zezwolenia ministra właściwego do spraw wewnętrznych na nabycie nieruchomości.

Glosowany wyrok Sądu Apelacyjnego należy uznać za słuszny i zasługujący na uwagę nie tylko ze względu na konstrukcję uzasadnienia zawierającego logiczną 
argumentację prawną dotyczącą interpretacji art. 8 ust. $2 \mathrm{UnNpC}$, lecz także na wskazanie kierunku wykładni innych przepisów UnNpC.

Regulacja ta, obowiązująca od 21 kwietnia 1920 r., była wielokrotnie nowelizowana na skutek zmieniającego się otoczenia prawnego i gospodarczego, a także zobowiązań międzynarodowych, w tym warunków przystąpienia Polski do Unii Europejskiej ${ }^{11}$. Po nowelizacji z 2004 r. wprowadzono do UnNpC kilka przepisów epizodycznych w związku z przyjętymi w Traktacie Akcesyjnym okresami przejściowymi, po upływie których przepisy te wymagają właściwej wykładni w celu rekonstrukcji zawartych w nich obowiązujących norm prawnych. Taki sposób odtworzenia normy prawnej zawartej w art. 8 ust. 2 UnNpC został zaprezentowany w glosowanym wyroku Sądu Apelacyjnego we Wrocławiu. Wykładnię językową art. 8 ust. 2 UnNpC wsparto w uzasadnieniu wyroku wykładnią systemową, funkcjonalną i celowościową w celu wskazania obywatelstwa - atrybutu osoby fizycznej, który jest łącznikiem dla tej grupy podmiotów decydującym o konieczności uzyskania zezwolenia na nabycie nieruchomości lub o zwolnieniu z jego uzyskania w świetle przepisów UnNpC.

Aprobując glosowany wyrok, można jego motywy wzmocnić lub nawet uzupełnić dodatkowymi argumentami przemawiającymi za słusznością dokonanej wykładni art. 8 ust. 2 UnNpC.

Po pierwsze, UnNpC ma charakter reglamentacyjny. Wprowadza ograniczenia o charakterze publicznoprawnym w obrocie nieruchomościami ze względów podmiotowych, tj. osobę nabywcy - cudzoziemca. Sprowadza się to do konieczności uzyskania zezwolenia ministra właściwego do spraw wewnętrznych, które ma charakter warunku prawnego (conditio iuris), a tym samym stanowi obligatoryjną część zdarzenia prawnego, w tym czynności prawnej nabycia nieruchomości przez cudzoziemca $^{12}$. Tym samym punktem wyjścia dla prawidłowej wykładni przepisów UnNpC jest zawarta w art. 1 ust. 2 UnNpC autonomiczna definicja cudzoziemca, którym jest: 1) osoba fizyczna nieposiadająca obywatelstwa polskiego; 2) osoba prawna mająca siedzibę za granicą; 3) nieposiadająca osobowości prawnej spółka osób wymienionych w pkt 1 lub 2, mająca siedzibę za granicą, utworzona zgodnie z ustawodawstwem państw obcych; 4) osoba prawna i spółka handlowa nieposiadająca osobowości prawnej, mająca siedzibę na terytorium Rzeczypospolitej Polskiej, kontrolowana bezpośrednio lub pośrednio przez osoby lub spółki wymienione

${ }_{11}$ W okresie od dnia wejścia w życie ustawy o nabywaniu nieruchomości przez obcokrajowców, tj. od 21 kwietnia 1920 r. (zmiana nazwy na ustawę o nabywaniu nieruchomości przez cudzoziemców nastąpiła z dniem 10 grudnia 1932 r.), do dnia 31 grudnia 2019 r. była ona 21 razy zmieniana i wydano jej 6 tekstów jednolitych.

${ }_{12}$ Zob. rozważania na temat istoty warunku prawnego oraz orzecznictwo dotyczące tej instytucji: J.J. Skoczylas, Cywilnoprawny obrót nieruchomościami przez cudzoziemców (po wejściu Polski do Unii Europejskiej), Warszawa 2004, s. 49-53; A. Bereza, ,Nabycie drugiego domu” przez cudzoziemców w świetle przepisów prawa polskiego, „Rejent” 2005, nr 5, s. 34-35. 
w pkt 1, 2 i 3. Katalog podmiotów uznanych za cudzoziemców jest zamknięty, a tym samym UnNpC nie przewiduje innej, odrębnej rodzajowo kategorii podmiotów (np. przedsiębiorców). W stosunku do osoby fizycznej jedyną przesłanką uznania jej za cudzoziemca jest okoliczność nieposiadania przez nią obywatelstwa polskiego (żadna inna cecha danej osoby czy okoliczność z nią związana nie jest w tym przypadku brana pod uwagę). Wskazany art. 1 ust. 2 UnNpC skorelowany jest $\mathrm{z}$ art. $43^{1}$ k.c., który nie przewiduje dodatkowej - poza osobą fizyczną, osobą prawną i jednostką organizacyjną niebędącą osobą prawną, której ustawa przyznaje zdolność prawną - kategorii podmiotu prawa określonego jako przedsiębiorca. Tym samym okoliczność prowadzenia działalności gospodarczej nie zmienia faktu, iż dany podmiot jest w świetle prawa nadal osobą fizyczną, osobą prawną lub jednostką organizacyjną niebędącą osobą prawną, której ustawa przyznaje zdolność prawną. Konsekwencją powyższego jest to, że nabycie nieruchomości nie następuje na rzecz przedsiębiorcy, lecz na rzecz określonego podmiotu prawa cywilnego, co na tle niniejszej sprawy wskazuje, że nabywcą jest nadal osoba fizyczna, a okoliczność prowadzenia przez nią działalności gospodarczej nie kreuje żadnej dodatkowej czy też odrębnej podmiotowości prawnej. Potwierdza to wpis w księdze wieczystej, w której prawo do nieruchomości jest ujawniane na rzecz osoby fizycznej lub osoby prawnej, nie zaś na rzecz ,przedsiębiorcy” dysponującego jakąś odrębną podmiotowością prawną w sferze obrotu nieruchomościami. Podobnie z chwilą zaprzestania prowadzenia jednoosobowej działalności gospodarczej prawo własności nabytej nieruchomości nie przechodzi z „przedsiębiorcy” na osobę fizyczną, która prowadziła taką działalność gospodarczą (a więc była przedsiębiorcą) w momencie nabycia nieruchomości. Wskazuje to na konieczność dystynkcji cech istotnych podmiotu, regulujących jego status prawny w obrocie nieruchomościami, od rodzaju lub przedmiotu działalności, jaką prowadzi, która nie nadaje mu odrębnej ani wtórnej podmiotowości cywilnoprawnej.

Po drugie, wykładnia pojęcia ,przedsiębiorcy państw - stron umowy o EOG”, kreującego zakres zwolnienia podmiotowego z art. 8 ust. $2 \mathrm{UnNpC}$, powinna dotyczyć celów instytucji prawnej zwolnienia z obowiązku uzyskania zezwolenia ministra właściwego do spraw wewnętrznych w oparciu o regulację UnNpC. Pojęcie to nie precyzuje, na czym ma polegać związek przedsiębiorcy z państwem - stroną umowy o EOG. Wykładnia ściśle językowa tego pojęcia może doprowadzić do absurdalnych wyników (np. ograniczenia tego pojęcia do przedsiębiorcy założonego przez Republikę Francji), dlatego konieczne jest w tym przypadku sięgnięcie do innych rodzajów wykładni, tj. logicznej, systemowej i funkcjonalnej. Jest to niezbędne z uwagi na cel UnNpC w kontekście warunków przystąpienia Polski do Unii Europejskiej. Taki sam model rozumowania przeprowadzono dla wykładni pojęcia „nabycie drugiego domu”. W tym przypadku wykładnia językowa może doprowadzić do niepożądanych wyników, które byłyby sprzeczne z zasadą swobody przepływu kapitału. Tym samym należy zauważyć, że wykładnia szczególnych po- 
jęć z UnNpC nie powinna opierać się na odrębnej wykładni językowej desygnatów (,przedsiębiorca”, „drugi dom”) budujących zakres przedmiotowy pojęcia. Przeprowadzona wykładnia „przedsiębiorcy państw - stron umowy o EOG”, w oparciu o reguły przyjęte w uzasadnieniu glosowanego wyroku Sądu Apelacyjnego, odpowiada woli racjonalnego ustawodawcy, bez konieczności bezpośredniego stosowania tego rodzaju wykładni subiektywnej, opartej na psychicznych intencjach ustawodawcy, która jest przez współczesną teorię prawa kwestionowana i odsuwana na plan dalszy jako metoda zawodna i mało użyteczna ${ }^{13}$. Wyniki wykładni językowej, logicznej, systemowej i funkcjonalnej, a także wykładni doktrynalnej wskazują, że łącznik pomiędzy „przedsiębiorcą” a „państwem - stroną umowy o EOG” opiera się przede wszystkim na teorii siedziby ${ }^{14}$. Jest to łącznik charakteryzujący osoby prawne lub inne jednostki organizacyjne niebędące osobami prawnymi, którym odrębne przepisy przyznają zdolność prawną, na co wskazuje definicja cudzoziemca $\mathrm{z}$ art. 1 ust. 2 pkt 2-4 UnNpC. W przypadku osób fizycznych łącznikiem tym jest obywatelstwo, co jednoznacznie wynika z art. 1 ust. 2 pkt 1 i art. 8 ust. 2 in principio UnNpC. Osoby fizyczne mają miejsce zamieszkania (art. 25 k.c.), a osoby fizyczne będące przedsiębiorcami wskazują przy wpisie do Centralnej Ewidencji i Informacji o Działalności Gospodarczej m.in. obywatelstwo, adres do doręczeń oraz - jeżeli przedsiębiorca takie miejsce posiada - adres stałego miejsca wykonywania działalności gospodarczej ${ }^{15}$. Odbiega to od ustawowego pojęcia „siedziby” wskazywanej w rejestrze przedsiębiorców przez podmioty niebędące osobami fizycznymi ${ }^{16}$. Ponadto cechą osoby fizycznej prowadzącej działalność gospodarczą (przedsiębiorcy w rozumieniu Kodeksu cywilnego) jest nadal obywatelstwo. Tym samym logiczne jest, że ze zwolnienia podmiotowego z art. 8 ust. 2 UnNpC korzystają dwie kategorie cudzoziemców: 1) obywatele państw - stron umowy o EOG (cudzoziemcy w rozumieniu art. 1 ust. 2 pkt $1 \mathrm{UnNpC}$ ), niezależnie od tego, czy prowadzą działalność gospodarczą na terytorium państw - stron umowy o EOG, oraz 2) „przedsiębiorcy państw - stron umowy o EOG”, tj. spółki (przez spółki rozumie się spółki prawa cywilnego lub handlowego, a także spółdzielnie oraz inne osoby prawne prawa publicznego lub prywatnego, z wyjątkiem spółek, których działalność nie jest nastawiona na osiąganie zysków) założone zgodnie z ustawo-

${ }^{13}$ Uchwała 7 sędziów SN z dnia 17 stycznia 2001 r., III CZP 49/00, OSNIC 2001, nr 4, poz. 53 , s. 21.

${ }^{14}$ I. Wereśniak-Masri, Nabywanie nieruchomości przez cudzoziemców. Komentarz, Warszawa 2017, s. 136-137; P. Szymczyk, Nabywanie nieruchomości rolnych w świetle nowelizacji przepisów o kształtowaniu ustroju rolnego, cz. III, „Nieruchomości” 2017, nr 5, s. 24. Autorzy nie analizowali problemu poruszonego $\mathrm{w}$ glosowanym wyroku.

15 Art. 5 ust. 1 pkt 5 i 6 ustawy z dnia 6 marca 2018 r. o Centralnej Ewidencji i Informacji o Działalności Gospodarczej i Punkcie Informacji dla Przedsiębiorcy (Dz.U. 2018, poz. 647).

16 Art. 3 i art. 38 pkt 1 lit. c ustawy z dnia 20 sierpnia 1997 r. o Krajowym Rejestrze Sądowym (t.j. Dz.U. 2019, poz. 1500 z późn. zm.). 
dawstwem państw - stron umowy o EOG i mające swoją siedzibę wewnątrz EOG (cudzoziemcy w rozumieniu art. 1 ust. 2 pkt $2-4 \mathrm{UnNpC}$ w zw. z art. 54 Traktatu o funkcjonowaniu Unii Europejskiej) ${ }^{17}$.

Po trzecie, celem UnNpC jest zapewnienie kontroli nad obrotem nieruchomościami z udziałem cudzoziemców z uwagi na ochronę istotnych interesów Rzeczypospolitej Polskiej. Zakres przedmiotowy obowiązywania UnNpC w świetle art. 1 ust. 4 UnNpC wskazuje na realizację zasady zupełności prawa reglamentującego nabywanie nieruchomości przez cudzoziemców ${ }^{18}$. Tym samym wyjątki od tej zasady nie powinny być interpretowane rozszerzająco, co potwierdza dotychczasowe orzecznictwo ${ }^{19}$. Kontrola tej sfery obrotu prawnego ma zapobiegać sytuacji, aby nabycie nieruchomości nie spowodowało zagrożenia obronności, bezpieczeństwa państwa lub porządku publicznego, a także nie sprzeciwiało się względom polityki społecznej i zdrowia społeczeństwa (art. 1a ust. 1 pkt $1 \mathrm{UnNpC}$ ). Kryteria te odpowiadają zakresowi pojęć „,bezpieczeństwo publiczne” i „porządek publiczny", które uzasadniają wprowadzenie środków ograniczających zasadę swobody przepływu kapitału (art. 65 ust. 1 lit. b Traktatu o funkcjonowaniu Unii Europejskiej). Te nieostre pojęcia zawarte w UnNpC kształtują granice uznania administracyjnego ministra właściwego do spraw wewnętrznych udzielającego zezwolenia na nabycie nieruchomości. Powyższe okoliczności są weryfikowane na etapie rozpatrywania wniosków cudzoziemców o udzielenie zezwolenia na nabycie nieruchomości, czemu służą uregulowania przewidziane w art. 1 ust. 1, art. 2 i art. 2a UnNpC, dające organowi uprawnienie do żądania szerokiego zakresu informacji umożliwiających zbadanie skutków potencjalnego nabycia nieruchomości w kontekście przesłanek negatywnych z art. 1a ust. 1 pkt 1 UnNpC. Przyjęcie poglądu sądu pierwszej instancji nie zabezpieczałoby interesu Rzeczypospolitej Polskiej w kontekście chronionych wartości (art. 1a ust. 1 pkt 1 UnNpC) z uwagi na dużą rozbieżność $\mathrm{w}$ czynionych ustaleniach $\mathrm{w}$ przypadku postępowania o udzielenie zezwolenia na nabycie nieruchomości i postępowania prowadzonego w celu zalegalizowania pobytu cudzoziemca na terytorium Rzeczypospolitej Polskiej. Należy bowiem mieć na uwadze, że obecnie - zgodnie z art. 4 ust. 2 pkt 1 ustawy z dnia

${ }^{17}$ Wyrok WSA w Warszawie z dnia 10 maja 2006 r., V SA/Wa 2183/05, niepublikowany. Na marginesie należy zauważyć, że ustawowe pojęcie „przedsiębiorców państw - stron umowy o EOG” jako grupy podmiotów zwolnionych z obowiązku uzyskania zezwolenia na nabycie nieruchomości budzi jeszcze dodatkową wątpliwość, gdyż powinna ona w świetle traktatowo zagwarantowanej zasady swobody przepływu kapitału oraz wykładni prawa polskiego wspierającego realizację tej zasady obejmować także inne podmioty - niemające statusu przedsiębiorcy, a posiadające zdolność do nabywania nieruchomości (np. fundacje i stowarzyszenia). Zob. I. Wereśniak-Masri, op. cit., s. 135.

${ }_{18}$ Od zasady tej są nieliczne wyjątki zakładające wyłączenie stosowania UnNpC. Zob. A. Bereza, Nabycie nieruchomości przez osoby fizyczne majace status cudzoziemca w świetle przepisów prawa polskiego, [w:] Prawne problemy członkostwa Polski w Unii Europejskiej, red. L. Leszczyński, Lublin 2005, s. 177.

${ }^{19}$ Uchwała SN z dnia 1 września 1993 r., III CZP 117/93, OSNC 1994, nr 2, poz. 37. 
6 marca 2018 r. o zasadach uczestnictwa przedsiębiorców zagranicznych i innych osób zagranicznych w obrocie gospodarczym na terytorium Rzeczypospolitej Polskiej - obywatele innych państw niż państwa członkowskie mogą podejmować i wykonywać działalność gospodarczą na terytorium Rzeczypospolitej Polskiej na takich samych zasadach jak obywatele polscy, jeżeli posiadają w Rzeczypospolitej Polskiej: zezwolenie na pobyt stały; zezwolenie na pobyt rezydenta długoterminowego Unii Europejskiej; zezwolenie na pobyt czasowy udzielone w związku z okolicznością, o której mowa w art. 144, art. 159 ust. 1 lub art. 186 ust. 1 pkt 3 i 4 ustawy z dnia 12 grudnia 2013 r. o cudzoziemcach; status uchodźcy; ochronę uzupełniającą; zgodę na pobyt ze względów humanitarnych lub zgodę na pobyt tolerowany; zezwolenie na pobyt czasowy i pozostają w związku małżeńskim zawartym z obywatelem polskim zamieszkałym na terytorium Rzeczypospolitej Polskiej; zezwolenie na pobyt czasowy w celu wykonywania działalności gospodarczej, udzielone ze względu na kontynuowanie prowadzonej już działalności gospodarczej na podstawie wpisu do Centralnej Ewidencji i Informacji o Działalności Gospodarczej ${ }^{20}$. Jednocześnie wskazać należy, że m.in. posiadanie zezwolenia na pobyt stały, zezwolenia na pobyt rezydenta długoterminowego Unii Europejskiej lub zezwolenia na pobyt czasowy ( $\mathrm{z}$ wyłączeniem zezwolenia, o którym mowa w art. 176 i art. 181 ust. 1 ustawy z dnia 12 grudnia 2013 r. o cudzoziemcach) stanowi zgodnie $\mathrm{z}$ art. 1a ust. 2 pkt 3 lit. a-c UnNpC okoliczność potwierdzającą więzi cudzoziemca z Rzecząpospolitą Polską umożliwiającą uzyskanie zezwolenia, a nie zwolnienie z obowiązku uzyskania zezwolenia ministra właściwego do spraw wewnętrznych na nabycie nieruchomości. Porównanie przepisów określających warunki uzyskania zezwolenia na pobyt na terytorium Rzeczypospolitej Polskiej z przepisami warunkującymi uzyskanie zezwolenia na nabycie nieruchomości wskazuje, że przyjęcie stanowiska sądu pierwszej instancji prowadziłoby do zaniechania stosowania przepisów UnNpC dotyczących zasad udzielania zezwoleń (w tym art. 1a ust. 1 pkt 1 UnNpC pozwalającego na badanie zagrożenia obronności, bezpieczeństwa państwa i porządku publicznego) przy nabywaniu nieruchomości przez osoby fizyczne niebędące obywatelami państw - stron umowy o EOG. Do takiej sytuacji mogłoby bowiem dochodzić w każdym przypadku poprzez jednostronną czynność samego cudzoziemca, tj. rozpoczęcie przez niego prowadzenia działalności gospodarczej, co czyniłoby obojętnym łącznik obywatelstwa decydujący o konieczności uzyskania zezwolenia na nabycie nieruchomości (położonych

${ }^{20}$ Art. 4 ust. 2 pkt 1 ustawy z dnia 6 marca 2018 r. o zasadach uczestnictwa przedsiębiorców zagranicznych i innych osób zagranicznych w obrocie gospodarczym na terytorium Rzeczypospolitej Polskiej (t.j. Dz.U. 2019, poz. 1079 z późn. zm.). Katalog ten ulegnie rozszerzeniu w różnych terminach po 1 stycznia 2020 r., lecz dla potrzeb niniejszej glosy jego omówienie jest zbędne. Inne kategorie cudzoziemców uprawnionych do prowadzenia działalności na takich samych zasadach jak obywatele polscy przewiduje art. 4 ust. 2 pkt 2-5 przywołanej wyżej ustawy. 
także $\mathrm{w}$ strefie nadgranicznej - zastrzeżenie $\mathrm{z}$ art. 8 ust. $3 \mathrm{UnNpC}$ nie dotyczy zwolnienia podmiotowego $\mathrm{z}$ analizowanego art. 8 ust. $2 \mathrm{UnNpC}$ ). W stosunku do takiej osoby niemożliwe będzie zbadanie przez ministra właściwego do spraw wewnętrznych i inne organy państwa (art. 2 i 2a UnNpC) występowania w danym przypadku przesłanek negatywnych, a tym samym ewentualnego zapobieżenia niepożądanym skutkom z punktu widzenia funkcjonowania państwa (np. ,pranie brudnych pieniędzy" czy finansowanie działalności grup ekstremistycznych), co z uwagi na bliską współpracę w zakresie obronności i bezpieczeństwa, a także na innych płaszczyznach jest znacząco ograniczone w ramach państw - stron umowy o EOG.

Tym samym przyjęcie stanowiska, że przedsiębiorcą państw - stron umowy o EOG jest także cudzoziemiec (osoba fizyczna niebędąca obywatelem państwa - strony umowy o EOG) prowadzący jednoosobową działalność gospodarczą na terytorium Rzeczypospolitej (oraz każdego innego państwa członkowskiego), oznaczałoby podważenie celu UnNpC. Każdy cudzoziemiec (również ten będący obywatelem państwa spoza kręgu państw - stron umowy o EOG lub Konfederacji Szwajcarskiej) mógłby nabyć bez żadnej kontroli niemalże każdą nieruchomość położoną w Polsce, wskazując $w$ akcie notarialnym, iż prowadzi działalność gospodarczą na terytorium Rzeczypospolitej Polskiej lub innego państwa członkowskiego. Taka sytuacja prowadziłaby do zniweczenia celu UnNpC, czyniąc kontrolę państwa iluzoryczną w zakresie ochrony istotnych wartości wskazanych w UnNpC.

Po czwarte, nie ma podstawy, aby do oceny stanu prawnego niniejszej sprawy bezpośrednio zastosować prawo Unii Europejskiej, w szczególności art. 63 Traktatu o funkcjonowaniu Unii Europejskiej dotyczący swobody przepływu kapitału. Zarówno Traktat o funkcjonowaniu Unii Europejskiej, jak i Traktat Akcesyjny nie odnoszą się do praw i obowiązków w zakresie nabywania nieruchomości na terytorium Rzeczypospolitej Polskiej przez podmioty (w tym przedsiębiorców) z państw trzecich, innych niż państwa - strony umowy o EOG, które prowadzą działalność gospodarczą na terytorium Rzeczypospolitej Polskiej na podstawie przepisów prawa krajowego przyjętych poza zakresem kompetencji Unii Europejskiej. Stan faktyczny sprawy będącej przedmiotem wyroku Sądu Apelacyjnego we Wrocławiu wskazuje na brak czynnika transgranicznego, a więc sprawa ta ma charakter wewnętrzny (okoliczności stanu faktycznego są ograniczone do terytorium Rzeczypospolitej Polskiej, na którym przedsiębiorca przebywa, prowadzi swoją działalność gospodarczą oraz położona jest na nim przedmiotowa nieruchomość), a tym samym nie następuje żaden przepływ kapitału między państwami członkowskimi a państwem trzecim.

Kwestia poruszona w glosowanym wyroku pojawiła się już na wokandzie sądów powszechnych. Wskazuje to, że budzi ona problemy interpretacyjne w praktyce notarialnej. W wyroku Sądu Okręgowego w Płocku z dnia 22 lutego 2017 r. (IV 
Ca 1012/16) ${ }^{21}$ zmieniono orzeczenie sądu pierwszej instancji i stwierdzono nieważność nabycia nieruchomości przez cudzoziemca - obywatela Rosji. Sąd Okręgowy w Płocku, opierając się na wykładni systemowej i celowościowej, zwrócił uwagę, iż okoliczność prowadzenia działalności gospodarczej na terenie Rzeczypospolitej Polskiej nie może z jednej strony być okolicznością potwierdzającą więzi z Polską, uzasadniającą wydanie zezwolenia na nabycie nieruchomości, a z drugiej strony stanowić podstawy do zwolnienia z obowiązku uzyskania zezwolenia. Tym samym pojawiła się już argumentacja, jaką można odnaleźć w glosowanym orzeczeniu, lecz w oparciu o zastosowaną wykładnię systemową i celowościową Sąd Okręgowy nie przeprowadził restryktywnej wykładni językowej art. 8 ust. 2 UnNpC. Uznał, że dla zrozumienia istoty tego przepisu wykładnia językowa jest niewystarczająca, a tylko wykładnia systemowa i celowościowa umożliwia zastosowanie art. 8 ust. 2 UnNpC zgodnie z zasadą racjonalnego ustawodawcy. Taką argumentację, opartą na niespójności przepisów UnNpC, które - co istotne - mają różną wagę z punktu widzenia uprawnień nabywcy nieruchomości, uzupełnia dopiero wykładnia językowa zawarta w uzasadnieniu glosowanego wyroku Sądu Apelacyjnego. To pokazuje, z jakimi nowymi problemami interpretacyjnymi stykają się sądy powszechne (zwłaszcza po upływie okresów przejściowych wynikających z Traktatu Akcesyjnego i wygaśnięciu charakteru reglamentacyjnego części normy prawnej zawartej w art. 8 ust. 2 UnNpC).

Przepisy UnNpC, znowelizowanej w celu dostosowania do postanowień Traktatu Akcesyjnego, pomimo upływu ponad 15 lat od ich wprowadzenia wciąż budzą spory interpretacyjne. Nie bez znaczenia dla tej sytuacji ma upływ okresów przejściowych - w czasie których wymagane było zezwolenie - nieruchomości rodzajowo wskazanych w UnNpC. Wymaga to uważniejszej rekonstrukcji normy prawnej zawartej w art. 8 ust. 2 UnNpC, którego część przestała mieć zastosowanie do czynności cudzoziemców związanych z uzyskaniem zezwolenia na nabycie nieruchomości (art. 8 ust. 2 pkt 1 UnNpC z dniem 1 maja 2016 r., a art. 8 ust. 2 pkt 2 UnNpC z dniem 1 maja 2009 r.). Glosowany wyrok Sądu Apelacyjnego we Wrocławiu zdaje się rozwiewać wątpliwości dotyczące wykładni nadal obowiązującego art. 8 ust. 2 UnNpC dotyczącego zakresu podmiotowego zwolnienia od obowiązku uzyskania zezwolenia na nabycie nieruchomości przez cudzoziemca. Glosowany wyrok nie zamyka ostatecznie problemu stosowania i wykładni pojęcia „przedsiębiorcy” w zakresie zwolnienia podmiotowego z art. 8 ust. $2 \mathrm{UnNpC}$, lecz wskazuje na kierunek wykładni tego przepisu. Jest to o tyle istotne, że poglądy

${ }^{21}$ Wyrok SO w Płocku z dnia 22 lutego 2017 r., IV Ca 1012/16, Legalis nr 2095880. 
przemawiające za wykładnią rozszerzającą zakresu podmiotowego zwolnienia $\mathrm{z}$ art. 8 ust. $2 \mathrm{UnNpC}$ na osoby fizyczne nieposiadające obywatelstwa państw - stron umowy o EOG albo Konfederacji Szwajcarskiej, prowadzące działalność gospodarczą na terytorium tych państw, uzyskując status przedsiębiorcy na podstawie obowiązującego w nich ustawodawstwa krajowego, podważałyby funkcje UnNpC. Nie znajdują one uzasadnienia także w oparciu o zastosowane reguły wykładni systemowej i celowościowej tego przepisu.

\section{BIBLIOGRAFIA}

\section{Literatura}

Bereza A., „Nabycie drugiego domu” przez cudzoziemców w świetle przepisów prawa polskiego, „Rejent” 2005, nr 5.

Bereza A., Nabycie nieruchomości przez osoby fizyczne mające status cudzoziemca $w$ świetle przepisów prawa polskiego, [w:] Prawne problemy członkostwa Polski w Unii Europejskiej, red. L. Leszczyński, Lublin 2005.

Franczak P., Powiernicze posiadanie udziałów a ustawa o nabywaniu nieruchomości przez cudzoziemców, „Monitor Prawniczy” 2016, nr 7.

Skoczylas J.J., Cywilnoprawny obrót nieruchomościami przez cudzoziemców (po wejściu Polski do Unii Europejskiej), Warszawa 2004.

Szymczyk P., Nabywanie nieruchomości rolnych $w$ świetle nowelizacji przepisów o kształtowaniu ustroju rolnego, cz. III, „Nieruchomości” 2017, nr 5.

Wereśniak-Masri I., Nabywanie nieruchomości przez cudzoziemców. Komentarz, Warszawa 2017.

\section{Akty prawne}

Akt dotyczący warunków przystąpienia do Unii Europejskiej Republiki Czeskiej, Republiki Estońskiej, Republiki Cypryjskiej, Republiki Łotewskiej, Republiki Litewskiej, Republiki Węgierskiej, Republiki Malty, Rzeczypospolitej Polskiej, Republiki Słowenii i Republiki Słowackiej oraz dostosowań w Traktatach stanowiących podstawę Unii Europejskiej, Załącznik XII „Wykaz, o którym mowa w artykule 24 Aktu Przystąpienia: Polska” (Dz.U. 2004, nr 90, poz. 865; Dz.Urz. UE L 236 z 23.09.2003 r.).

Protokół do umowy między Wspólnotą Europejską i jej Państwami Członkowskimi, z jednej strony, a Konfederacją Szwajcarską, z drugiej strony, w sprawie swobodnego przepływu osób z dnia 26 października 2004 r. (Dz.Urz. UE L 89 z 28.03.2006 r.).

Ustawa z dnia 24 marca 1920 r. o nabywaniu nieruchomości przez cudzoziemców (t.j. Dz.U. 2017, poz. 2278 z późn. zm.).

Ustawa z dnia 23 kwietnia 1964 r. - Kodeks cywilny (t.j. Dz.U. 2019, poz. 1145).

Ustawa z dnia 20 sierpnia 1997 r. o Krajowym Rejestrze Sądowym (t.j. Dz.U. 2019, poz. 1500 z późn. zm.).

Ustawa z dnia 20 lutego 2004 r. o zmianie ustawy o nabywaniu nieruchomości przez cudzoziemców i ustawy o opłacie skarbowej (Dz.U. nr 49, poz. 466). 
Ustawa z dnia 16 kwietnia 2004 r. o ratyfikacji Porozumienia w sprawie udziału Republiki Czeskiej, Republiki Estońskiej, Republiki Cypryjskiej, Republiki Łotewskiej, Republiki Litewskiej, Republiki Węgierskiej, Republiki Malty, Rzeczypospolitej Polskiej, Republiki Słowenii i Republiki Słowackiej w Europejskim Obszarze Gospodarczym, podpisanego w Brukseli w dniu 14 października 2003 r. (Dz.U. 2004, nr 130, poz. 1375).

Ustawa z dnia 2 lipca 2004 r. o swobodzie działalności gospodarczej (t.j. Dz.U. 2015, poz. 584 z późn. zm.).

Ustawa z dnia 5 września 2008 r. o zmianie niektórych ustaw w związku z wejściem w życie Protokołu do Umowy między Wspólnotą Europejską i jej Państwami Członkowskimi, z jednej strony, a Konfederacją Szwajcarską, z drugiej strony, w sprawie swobodnego przepływu osób (Dz.U. nr 180, poz. 1112).

Ustawa z dnia 6 marca 2018 r. o Centralnej Ewidencji i Informacji o Działalności Gospodarczej i Punkcie Informacji dla Przedsiębiorcy (Dz.U. 2018, poz. 647).

Ustawa z dnia 6 marca 2018 r. o zasadach uczestnictwa przedsiębiorców zagranicznych i innych osób zagranicznych w obrocie gospodarczym na terytorium Rzeczypospolitej Polskiej (t.j. Dz.U. 2019, poz. 1079 z późn. zm.).

\section{Orzecznictwo}

Uchwała SN z dnia 1 września 1993 r., III CZP 117/93, OSNC 1994, nr 2, poz. 37.

Uchwała 7 sędziów SN z dnia 17 stycznia 2001 r., III CZP 49/00, OSNIC 2001, nr 4, poz. 53.

Wyrok SA w Poznaniu z dnia 2 grudnia 2008 r., I ACa 699/08, Legalis nr 216236.

Wyrok SA we Wrocławiu z dnia 29 października 2019 r., I ACa 698/19, niepublikowany.

Wyrok SO w Płocku z dnia 22 lutego 2017 r., IV Ca 1012/16, Legalis nr 2095880.

Wyrok WSA w Warszawie z dnia 10 maja 2006 r., V SA/Wa 2183/05, niepublikowany.

\section{SUMMARY}

The Court of Appeal in Wrocław, in its judgement of 29 October 2019 (I ACa 698/19) amending the judgement of the District Court of Wrocław of 28 February 2019 (I C733/18), declared invalid the acquisition of a real property by a South Korean citizen. In its judgement, the Court of Appeal in Wrocław interpreted Article 8 (2) of the Act of 24 March 1920 on the Acquisition of Real Property by Foreigners. This provision governs the subjective scope of the exemption from the obligation to obtain the authorisation from the minister competent for interior affairs for the acquisition of real property. The Court of Appeal has concluded that a natural person who is a foreign person within the meaning of the Act on the Acquisition of Real Property by Foreigners and who is not a citizen of the European Economic Area Member State or the Swiss Confederation, even though pursues individual economic activity in the territory of the Republic of Poland, shall not be entitled to the exemption provided for in Article 8 (2) of the Act on the Acquisition of Real Property by Foreigners concerning nationals and undertakings of the Member States of the European Economic Area agreement or the Swiss Confederation, as this would be contrary to the function of the Act on the Acquisition of Real Property by Foreigners and the systemic and teleological interpretation of Article 8 (2) of this Act.

Keywords: acquisition of a real estate by foreigners; exemption from obtaining the authorisation of the minister competent for interior affairs; Accession Treaty; European Economic Area 